\title{
INFLUENCE OF SILICA FUME INCORPORATION ON THE FRESH AND MECHANICAL PROPERTIES OF EXPANDED POLYSTYRENE (EPS) FOAMED CONCRETE
}

\author{
M. A. A. ElAziz, A. Serag and M. M. A. Kamel \\ Department of Civil Engineering, Faculty of Engineering, Fayoum University.
}

\begin{abstract}
This paper aims to study both fresh and mechanical properties of lightweight concrete (LWC) incorporating expanded polystyrene foam (EPS) beads as a lightweight aggregates (LWA). Various mixtures of EPS foamed concrete are produced by partial replacing normal aggregates by $0 \%, 15 \%, 25 \%$ and $50 \%$ of EPS foam beads by volume. In EPS foamed concrete the ordinary Portland cement (OPC) was replaced by silica fume (SF) with different ratios $0 \%, 5 \%, 10$ and $15 \%$ by weight. Sixteen mixtures are prepared to investigate the properties of EPS foamed concrete. The tests program includes determination of fresh density, slump, compacting factor, compressive strength, splitting tensile strength, flexural strength and modulus of elasticity. Generally, using of EPS beads in concrete decreases its mechanical properties, although the workability improvement. On the other hand, replacing the OPC with SF improves mechanical properties of EPS foamed concrete. This improvement continues to the percentage of $10 \%$ and ultimate improvement at the ratio of $5 \%$. Modulus of elasticity improves in EPS foamed concrete with SF content till 25\% EPS foam. The workability of EPS foamed concrete decreases with the increasing of SF ratios.
\end{abstract}

\section{INTRODUCTION}

Using alternative affordable and sustainable products is a trend already well-established among the research community worldwide [1]. According to Bouvard $\boldsymbol{e t}$ al. [2], the interest in LWC to decrease the volume of load-bearing elements and get better properties comparing with conventional concrete. In general, lightweight aggregates are broadly classified into two types: natural (e.g., pumice, diatomite, volcanic cinder) and artificial (e.g., perlite, clay, sintered fly ash, expanded shale). Polystyrene beads are a widely used aggregate that can be easily incorporated into concrete or mortar to produce lightweight concrete with a wide range of densities [3].

EPS foams have a cellular microstructure with closed cell membranes made of expandable polystyrene (EPS) and its density is typically less than $50 \mathrm{~kg} / \mathrm{m}^{3}$ [4]. Recently applications of EPS lightweight concrete include cladding panels, curtain walls, composite flooring systems, load-bearing concrete blocks, sub-base material for pavements, and floating marine structures, as well as impact-resistant structural protection layers, because of the good energy-absorbing characteristics of LWC [5].

Schackow et al. (2014) [6] reported that the EPS lightweight concrete has the advantage that the EPS particles that can be derived from recycling, do not absorb water as vermiculite does. It is suitable for developing concretes for both structural and non-structural applications by varying its volume percentage in mortar or concrete [7]. On the other hand, most of researches found during this study shows that an increase in EPS foam content will lead to a decrease in the compressive strength and other mechanical properties of concrete [9-11]. The 
improvement in the workability of fresh concrete increases with increasing foam content [5, 12].

Silica fume (SF) is a very fine non crystalline silica produced in electric furnaces ACI 116R [13]. SF is well known to improve the mechanical characteristics of concrete, the principal physical of its effect on concrete is being a filler which efficiently reduces permeability and adversely reduces the PH value $[\mathbf{1 4}, \mathbf{1 5}]$. Fresh concrete containing SF is more cohesive and less prone to segregation than concrete without it and the water demand for concrete containing SF increases with increasing amounts of silica, due to the high surface area of SF [16].

In this paper, the main objective was to provide some basic information about the mechanical and fresh properties of EPS lightweight concrete. Also the effect of SF on EPS concrete was investigated.

\section{EXPERIMENTAL STUDY}

\subsection{Materials}

The materials used in this work were ordinary Portland cement (OPC), fine aggregate, coarse aggregate, EPS foam beads and silica fume powder (SF). The physical properties of cement is confirming with ASTM C150 [17] Type I. The normal weight fine aggregate used was river sand with a fineness modulus and specific gravity of 2.2 and 2.6 respectively; while the used coarse aggregate was crushed stone (basalt) with a maximum particle size of $19 \mathrm{~mm}$ and 2.72 specific gravity. The EPS foam properties are defined as shown in Table 1 . The mean particle size of SF was $0.1 \mu \mathrm{m}$ and its bulk density was defined as $300 \mathrm{Kg} / \mathrm{m}^{3}$. The mineralogical composition of OPC and SF are listed in Table 2.

Table 1. Chemical and physical properties of EPS foam.

\begin{tabular}{ccccc}
\hline Molecular weight & $\begin{array}{c}\text { Density } \\
\left(\mathbf{k g} / \mathbf{m}^{\mathbf{3}}\right)\end{array}$ & $\begin{array}{c}\text { Beads } \\
\text { Diameter } \\
(\mathbf{m m})\end{array}$ & $\begin{array}{c}\text { Thermal } \\
\text { conductivity } \\
\mathbf{W} /(\mathbf{m} . \mathbf{K})\end{array}$ & $\begin{array}{c}\text { Compressive } \\
\text { strength }\left(\mathbf{N} / \mathbf{c m}^{\mathbf{2}}\right)\end{array}$ \\
\hline 300,000 & 17 & $0.6-1.4$ & 0.04 & 10 \\
\hline
\end{tabular}

Table 2. Chemical composition of used OPC and SF

\begin{tabular}{lcc}
\hline \multirow{2}{*}{ Compositions } & \multicolumn{2}{c}{ Percentage of Weight $(\%)$} \\
\cline { 2 - 3 } Wt.)
\end{tabular}

\subsection{Mix Proportions}

The mix composition of the investigated mixes is seen in Table 3. For the anticipated testing exactly sixteen different mixtures of component materials were produced according to ECP 203 [18] (they are 
labeled as E for EPS foam and S for SF; then followed by the percentage). The EPS foam aggregate was used as $0 \%, 15 \%, 25 \%$ and $50 \%$ of natural aggregate by volume. The OPC replaced by weight with $0 \%, 5 \%, 10 \%$ and $15 \%$ SF percentages. Water to binder ratio was constant in all mixtures $(0.45)$. Mixing was performed in a horizontal pan mixer of 50 liter capacity in the laboratory. The mixing of materials was done in a specific sequence, by placing a part of the water in the mixture and adding the dry EPS aggregates, which was thoroughly mixed for about 5 min to get the aggregates wetted with water. Then, the remaining materials were added to the mixer and the remaining water was gradually added while the mixing was in progress. The mixing was continued until a mix of uniform consistency was achieved. They were removed from the molds $24 \mathrm{~h}$ after casting. Once removed from the molds, all of the specimens were moved to moist curing tank in the lab that meet the ASTM C511 [19] standards, where they remained undisturbed for the remainder of the curing process under constant temperature $24^{\circ} \mathrm{C}$.

\subsection{Experimental Procedure}

The fresh concrete densities, slump and compacting factor values were measured immediately after mixing for all the concretes according to ECP 203, ASTM C138 and ASTM C143 respectively $[18,20,21]$. The concrete specimens were cast in steel molds, followed immediately by curing at room temperature for $24 \mathrm{~h}$ before being demolded. After demolding, the specimens were stored in a control room maintained at $24 \pm 1{ }^{\circ} \mathrm{C}$ and $95 \% \mathrm{RH}$, and stored in water for curing until testing. The test specimens were cast with hand compaction only. The density of hardened EPS concrete test was conducted in accordance with ASTM C567 [22] at the age of 7 and 28 days. The compressive strength of hardened EPS lightweight concretes was measured on cube specimens $(150 \mathrm{~mm}$ x $150 \mathrm{~mm}$ x150 $\mathrm{mm}$ ) at the age of 7 and 28 days, at a loading rate of $2.5 \mathrm{kN} / \mathrm{s}$ according to ASTM C39 [23]; also moduli of elasticity was calculated on the same cube specimens at the age of 28 days, as per ASTM C469 [24]. Cylindrical samples of $150 \mathrm{~mm}$ diameter and $300 \mathrm{~mm}$ height were cast to study the splitting tensile strength behavior, which carried out in accordance with ASTM C496 [25] at the 7 and 28 days age. The two point load flexural strength test was conducted according to ASTM C78 [26] at the age of 28 days using $150 \mathrm{~mm} \times 150 \mathrm{~mm} \times 750 \mathrm{~mm}$ prisms.

Table 3. Mixing design of EPS foamed concrete with SF.

\begin{tabular}{lccccc}
\hline Mix Name & $\begin{array}{c}\text { OPC } \\
\left(\mathbf{K g} / \mathbf{m}^{3}\right)\end{array}$ & $\begin{array}{c}\text { Sand } \\
\left(\mathbf{K g} / \mathbf{m}^{3}\right)\end{array}$ & $\begin{array}{c}\text { Basalt } \\
\left(\mathbf{K g} / \mathbf{m}^{3}\right)\end{array}$ & $\begin{array}{c}\text { SF } \\
\left(\mathbf{K g} / \mathbf{m}^{3}\right)\end{array}$ & $\begin{array}{c}\text { EPS Foam } \\
\left(\mathbf{L i t} / \mathbf{m}^{3}\right)\end{array}$ \\
\hline E0S0 & 400 & 612 & 1224 & 0 & 0 \\
E0S5 & 380 & 612 & 1224 & 20 & 0 \\
E0S10 & 360 & 612 & 1224 & 40 & 0 \\
E0S15 & 340 & 612 & 1224 & 60 & 0 \\
\hline E15S0 & 400 & 525 & 1035 & 0 & 171 \\
E15S5 & 380 & 525 & 1035 & 20 & 171 \\
E15S10 & 360 & 525 & 1035 & 40 & 171 \\
E15S15 & 340 & 525 & 1035 & 60 & 171 \\
\hline E25S0 & 400 & 467 & 910 & 0 & 286 \\
E25S5 & 380 & 467 & 910 & 20 & 286 \\
E25S10 & 360 & 467 & 910 & 40 & 286 \\
E25S15 & 340 & 467 & 910 & 60 & 286 \\
\hline E50S0 & 400 & 321 & 595 & 0 & 572 \\
E50S5 & 380 & 321 & 595 & 20 & 572 \\
E50S10 & 360 & 321 & 595 & 40 & 572 \\
E50S15 & 340 & 321 & 595 & 60 & 572 \\
\hline & & & & &
\end{tabular}




\section{RESULTS AND DISCUSSION}

\subsection{Fresh Concrete Properties}

\subsubsection{Density}

The fresh EPS foamed concrete density varies from $2262 \mathrm{~kg} / \mathrm{m}^{3}$ to $1509 \mathrm{~kg} / \mathrm{m}^{3}$. The increasing of the EPS ratio decreases the fresh density. Density of fresh EPS concrete decreases by $10 \%, 18 \%$ and $36 \%$ with increasing the percentage of EPS foam in LWC $15 \%$, $25 \%$ and $50 \%$ respectively from Table 4 . On other hand, replacing SF by $10 \%$ and $15 \%$ percentages reduces the density of fresh EPS concrete.

Table 4: Fresh properties results.

\begin{tabular}{|l|c|c|c|}
\hline Mix Name & $\begin{array}{c}\text { Fresh Concrete Density } \\
\left(\mathbf{K g} \mathbf{m}^{\mathbf{3}}\right)\end{array}$ & Slump $(\mathbf{m m})$ & $\begin{array}{c}\text { Compacting } \\
\text { Factor }\end{array}$ \\
\hline CM & 2503 & 20 & 0.79 \\
\hline E0S5 & 2512 & 18 & 0.89 \\
\hline E0S10 & 2503 & 16 & 0.76 \\
\hline E0S15 & 2481 & 12 & 0.68 \\
\hline E15S0 & 2262 & 28 & 0.84 \\
\hline E15S5 & 2278 & 28 & 0.86 \\
\hline E15S10 & 2219 & 14 & 0.78 \\
\hline E15S15 & 2210 & 15 & 0.72 \\
\hline E25S0 & 2050 & 38 & 0.85 \\
\hline E25S5 & 2073 & 53 & 0.94 \\
\hline E25S10 & 2034 & 34 & 0.95 \\
\hline E25S15 & 2007 & 22 & 0.88 \\
\hline E50S0 & 1608 & 42 & 0.90 \\
\hline E50S5 & 1538 & 59 & 0.98 \\
\hline E50S10 & 1553 & 42 & 0.95 \\
\hline E50S15 & 1509 & 22 & 0.77 \\
\hline
\end{tabular}

\subsubsection{Workability}

The consistency of fresh concrete is evaluated in terms of the slump test. The values of the test ranged between $20 \mathrm{~mm}$ to $59 \mathrm{~mm}$. The increasing of EPS ratio increases the slump of the fresh LWC as plotted in Figure 1. These results is in agreement with $[\mathbf{1 1 , 2 7 , 2 8 ]}$. The increasing of the workability is occurred due to the decreasing of the bulk density of the EPS concrete while the volume of the cement paste increasing. In addition, small spherical bubbles in the foam act like ball bearings, thereby "lubricating" the paste and improving the workability; the results are in agreement with Chen and Liu [5]. As the EPS ratio increases, the slump of the fresh EPS concrete increases. The slump improvement ranges from $40 \%$ to $195 \%$ at EPS foam content from $15 \%$ to $50 \%$ respectively. Using large quantities of SF in EPS foam concrete in (10\% and 15\%) decreases the slump value. Slump results show that, the increasing of SF percentages decrease the slump value in normal density concrete (NDC). The 5\% SF percentage improves the slump in EPS foamed concrete. While, the slump value of $10 \%$ and $15 \% \mathrm{SF}$ decreases, but the values still higher than reference mix at replacing the aggregates with 25\% EPS foam or more. The increasing EPS foam in LWC with SF increases the slump value in most percentages, except 15\% EPS foam with 10\% SF and 50\% EPS foam with $15 \%$ SF, as shown in Figure 1. On other hand, the increase of the percentage of SF in EPS concrete reduces the compacting factor for most mixtures, except which contains $10 \%$ SF and $25 \%$ EPS foam. 

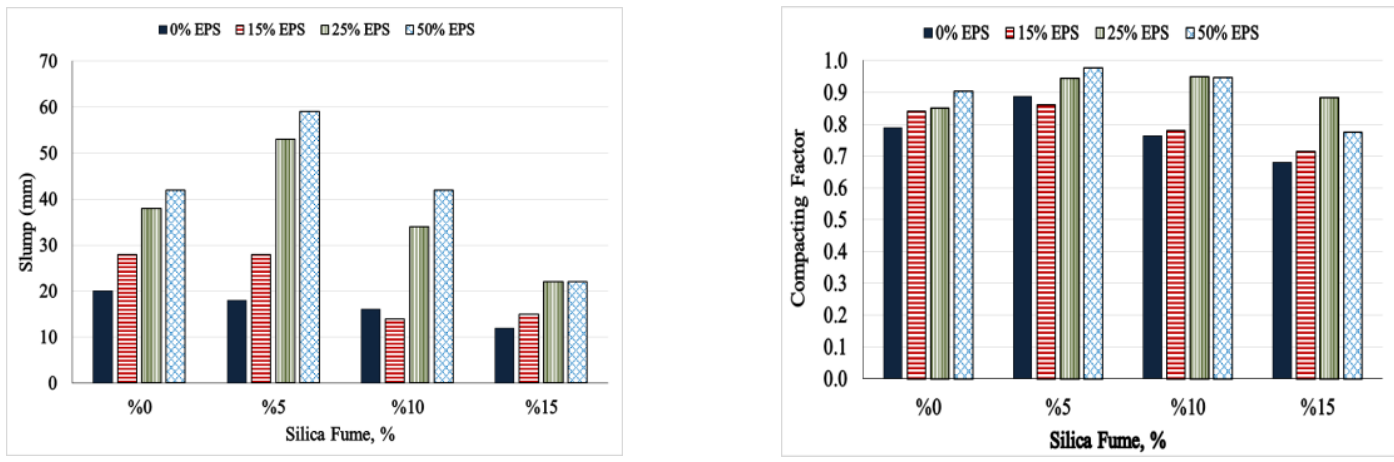

\subsection{Mechanical Properties}

Figure 1: Effect of SF on slump and compacting factor of EPS foamed concrete

\subsubsection{Hardened Density}

Density is one of the important parameters, which can control many properties in lightweight concrete and it is mainly controlled by the amount and density of lightweight aggregate [9]. It can be observed from Table 5 that, for most of the specimens, the early age hardened densities of EPS concrete (7 days) are higher than later age densities (28 days); this result in agreement with the relation utilized by Holm [29].

\subsubsection{Compressive Strength}

The compressive strength of 7 and 28 days results are presented in Table 5 and Figure 2 . The data shows that there are a systematic nonlinear decrease in the compressive strength as the EPS foam content is increased. The highest decrement is $(78.8 \%)$ for E50S0 mixture at 7 days, while at the age of 28 days the highest decrement ratio in average compressive strength $(80.4 \%)$ for the same mixture. The compressive strength increases with using SF in NDC as per ACI 234R-06 [16]. Figure 2 indicates that, the $10 \%$ percentage of SF gives the maximum compressive strength in NDC. On the other hand, the maximum improvement in EPS concrete occurred at the ratio of 5\% SF. The good effect of SF on the EPS foamed concrete compressive strength continuous till 25\% EPS foam. While, the higher percentage of SF $(15 \%)$ decreases the compressive strength in EPS foam concrete for most specimens.

Table 5: Mechanical properties results.

\begin{tabular}{|c|c|c|c|c|c|c|c|c|}
\hline \multirow[t]{2}{*}{$\begin{array}{l}\text { Mix } \\
\text { Name }\end{array}$} & \multicolumn{2}{|c|}{$\begin{array}{l}\text { Hardened Density } \\
\qquad \mathrm{kg} / \mathrm{m}^{3}\end{array}$} & \multicolumn{2}{|c|}{$\begin{array}{c}\text { Average } \\
\text { Compressive } \\
\text { Strength }\left(\mathbf{K g} / \mathbf{c m}^{2}\right)\end{array}$} & \multicolumn{2}{|c|}{$\begin{array}{c}\text { Average } \\
\text { Splitting Tensile } \\
\text { Strength }\left(\mathrm{Kg} / \mathrm{cm}^{2}\right)\end{array}$} & \multirow{2}{*}{$\begin{array}{c}\begin{array}{c}\text { Modulus of } \\
\text { Rupture } \\
\text { (Kg/cm²) }\end{array} \\
28 \text { Days }\end{array}$} & \multirow{2}{*}{$\begin{array}{l}\begin{array}{c}\text { Modulus } \\
\text { of } \\
\text { Elasticity } \\
\left(\mathbf{K g} / \mathbf{c m}^{2}\right)\end{array} \\
28 \text { Days }\end{array}$} \\
\hline & 7 Days & 28 Days & 7 Days & 28 Days & 7 Days & 28 Days & & \\
\hline CM & 2484 & 2449 & 260.1 & 340.4 & 19.8 & 24.5 & 41.8 & 24699 \\
\hline E0S5 & 2581 & 2559 & 287.4 & 400.3 & 22.2 & 29.2 & 38.8 & 28533 \\
\hline E0S10 & 2532 & 2496 & 344.7 & 471.9 & 25.8 & 34.9 & 42.5 & 28482 \\
\hline E0S15 & 2449 & 2412 & 219.2 & 312.0 & 20.4 & 26.4 & 28.1 & 22217 \\
\hline E15S0 & 2202 & 2148 & 192.7 & 237.3 & 15.1 & 21.0 & 31.3 & 12239 \\
\hline E15S5 & 2339 & 2315 & 210.1 & 273.6 & 18.3 & 27.6 & 29.3 & 14353 \\
\hline E15S10 & 2341 & 2287 & 208.6 & 277.1 & 18.3 & 27.0 & 29.7 & 14019 \\
\hline E15S15 & 2248 & 2190 & 166.9 & 226.2 & 16.7 & 24.1 & 24.7 & 10681 \\
\hline E25S0 & 2034 & 1965 & 125.8 & 139.4 & 11.6 & 16.6 & 27.1 & 11126 \\
\hline E25S5 & 2041 & 1978 & 168.3 & 208.7 & 11.9 & 18.5 & 22.3 & 12016 \\
\hline E25S10 & 2090 & 2031 & 135.7 & 159.1 & 10.4 & 15.8 & 22.9 & 9642 \\
\hline E25S15 & 2029 & 2026 & 134.4 & 173.6 & 11.5 & 17.6 & 20.3 & 9569 \\
\hline E50S0 & 1549 & 1486 & 55.3 & 66.7 & 8.4 & 11.1 & 16.1 & 6453 \\
\hline E50S5 & 1566 & 1559 & 50.6 & 58.9 & 6.2 & 8.9 & 15.1 & 5563 \\
\hline E50S10 & 1485 & 1488 & 37.4 & 52.9 & 7.0 & 9.8 & 15.2 & 6230 \\
\hline E50S15 & 1482 & 1475 & 36.4 & 48.7 & 6.0 & 8.2 & 14.8 & 5340 \\
\hline
\end{tabular}



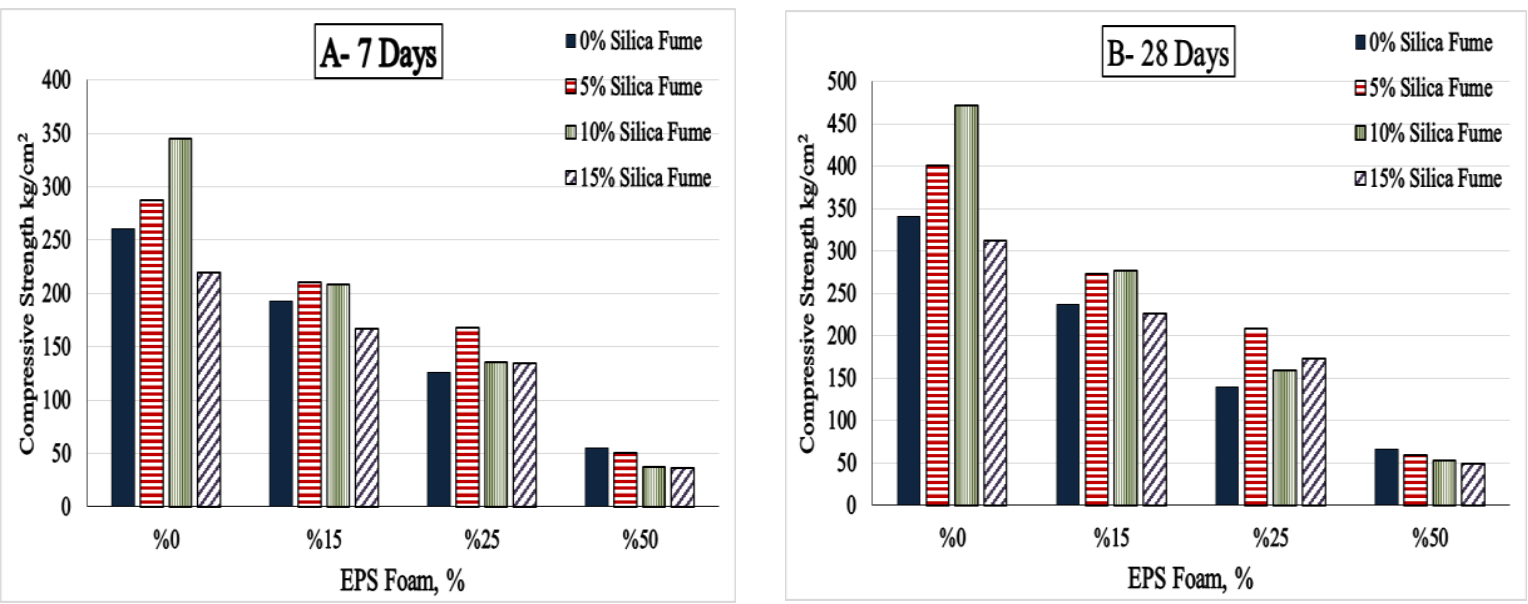

\subsubsection{Tensile Strength}

Figure 2: Effect of SF on compressive strength of EPS foamed concrete.

The tensile strength increases with the increase of SF in NDC; while the EPS foamed concrete tensile strength decreased with the increase of EPS foam ratio. Table 5 presents the results for early and late ages splitting tensile strength. The percentage of decrement in splitting tensile strength is less than the decrement in compressive strength at the same ages. The decrement of EPS concrete splitting tensile strength in early ages ( 7 days) is more than the late ages (28 days) that for the all test specimens. The difference of tensile strength decrement between early and late ages is significantly high in LWC with lower amount of EPS foam (15\% and 25\%), while the difference is low with high EPS foam percentage (50\%). It is clear from Figure 3 that, the optimum improvement in splitting tensile strength occurs at mixture E0S10 in NDC. On the other hand, the optimum improvement is developed with mixtures E15S5 and E25S5 and E50S5 for EPS foamed concrete. The improvement of tensile strength with SF in EPS foamed concrete is continued till 25\% EPS foam content, after that no more improvement appears with SF percentages.
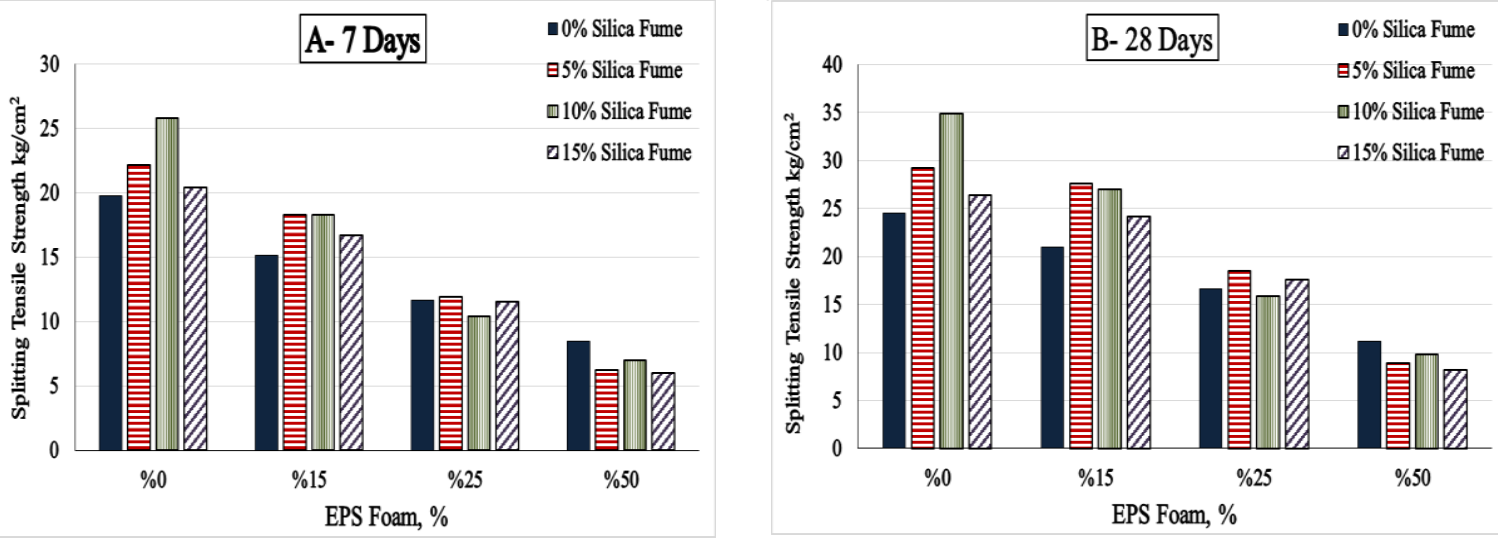

\subsubsection{Flexural Strength}

Figure 2: Effect of SF on splitting tensile strength of EPS foamed concrete.

The modulus of rupture was found to share a similar relationship with EPS foam content as other mechanical properties as presented in table 5. The value of modulus of rupture systematically decreased nonlinearly as the EPS foam content increased from $0 \%$ to $50 \%$. At higher levels of replacing EPS foam (25\% and 50\%) the decrement in flexural strength is higher than tensile strength but lower than compressive strength Table 5. Flexural strength increased with adding SF in NDC such as other mechanical properties. Figure 4 indicates that, the flexural strength improves with the ratio of $10 \%$ SF only in NDC. Otherwise, the SF doesn't improve the flexural strength in EPS foamed concrete. 


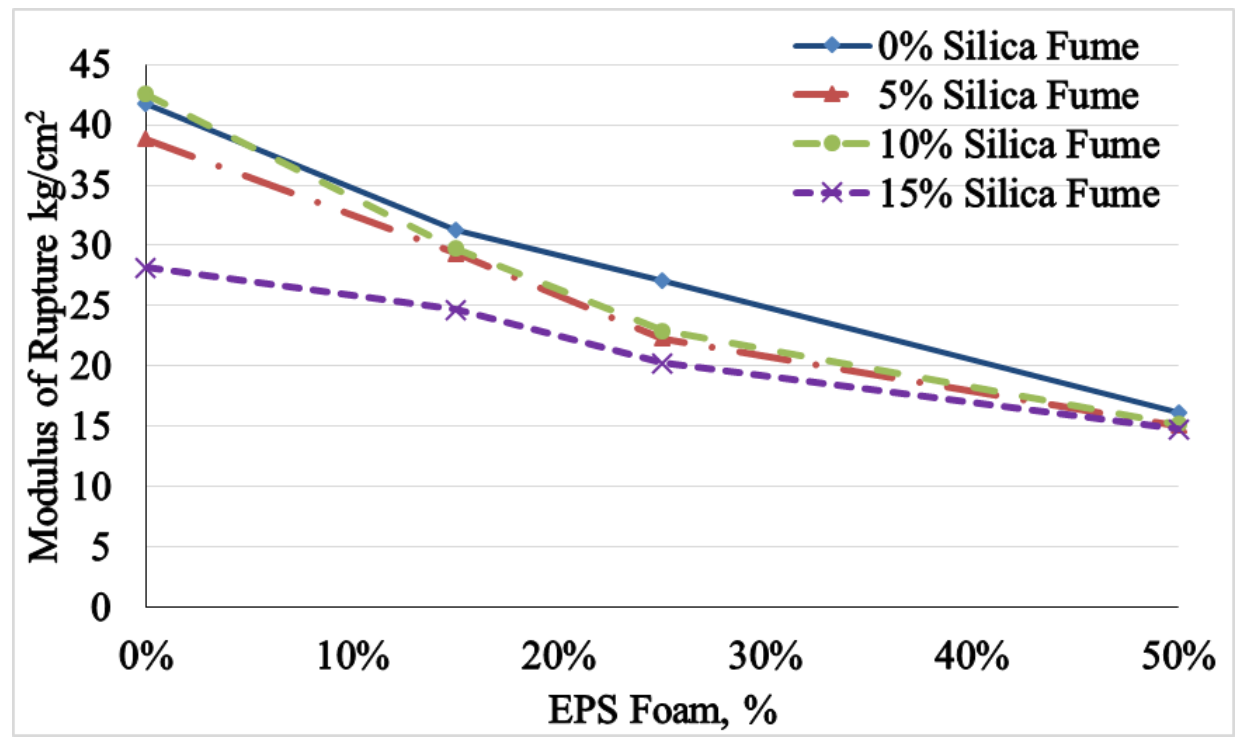

Figure 3: Effect of SF on modulus of rupture of EPS foamed concrete

For the control specimens and the specimens of lower EPS foam contents, the cracks and splitting occurred at a rate that was too fast to observe. For specimens with an EPS foam content of 50\% the crack propagation could be observed as it extended from the bottom face of the beam until the test ended due to the failure criteria without splitting Photo 1.

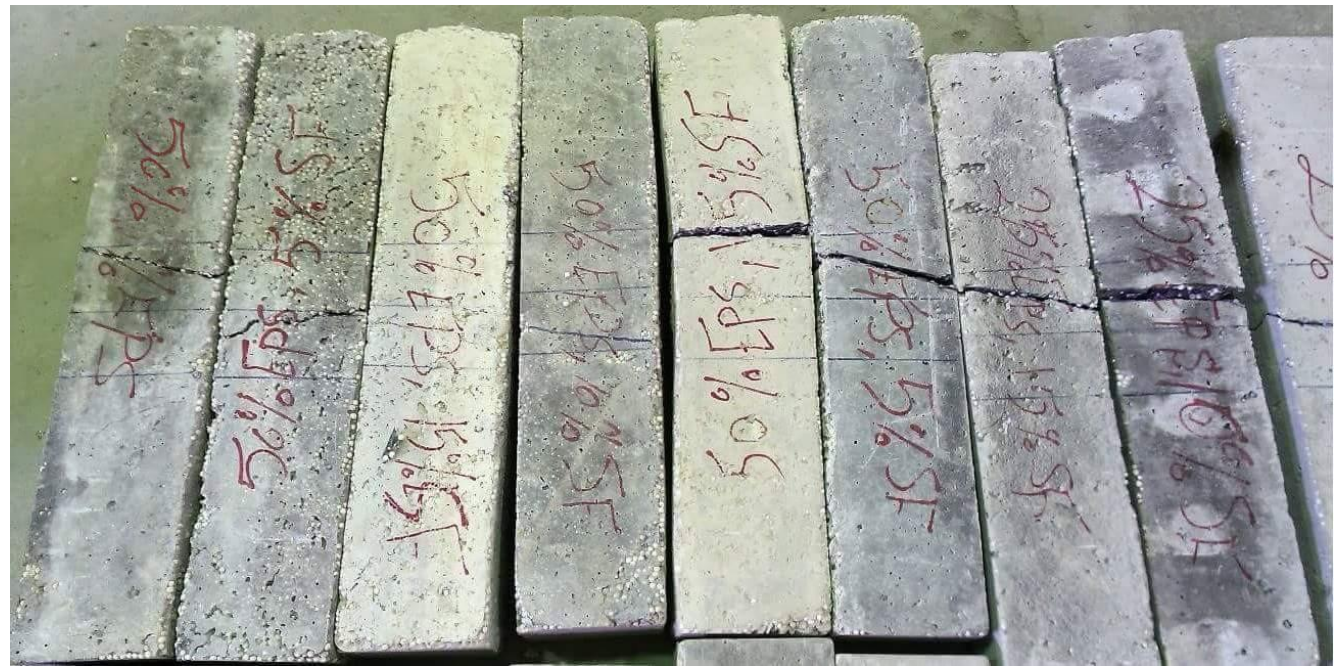

Photo 1: Failure modes of EPS foam concrete beams with SF percentages under flexural strength

\subsubsection{Modulus Of Elasticity}

From Table 5 the value of Elasticity is decreasing with the EPS foam percentage increasing. The highest decrement is obtained at EPS $50 \%$ mixture with ratio of $74 \%$ for specimen E50S0. It is clear from Figure 5 that, SF with ratios 5\% and $10 \%$ enhances the EPS foamed concrete modulus of elasticity until the ratios of $25 \%$ and $15 \%$ EPS foam respectively. The optimum percentage of SF that improves EPS concrete is 5\%. On other hand, the ratio $15 \%$ SF doesn't improve the EPS foamed concrete modulus of elasticity. 


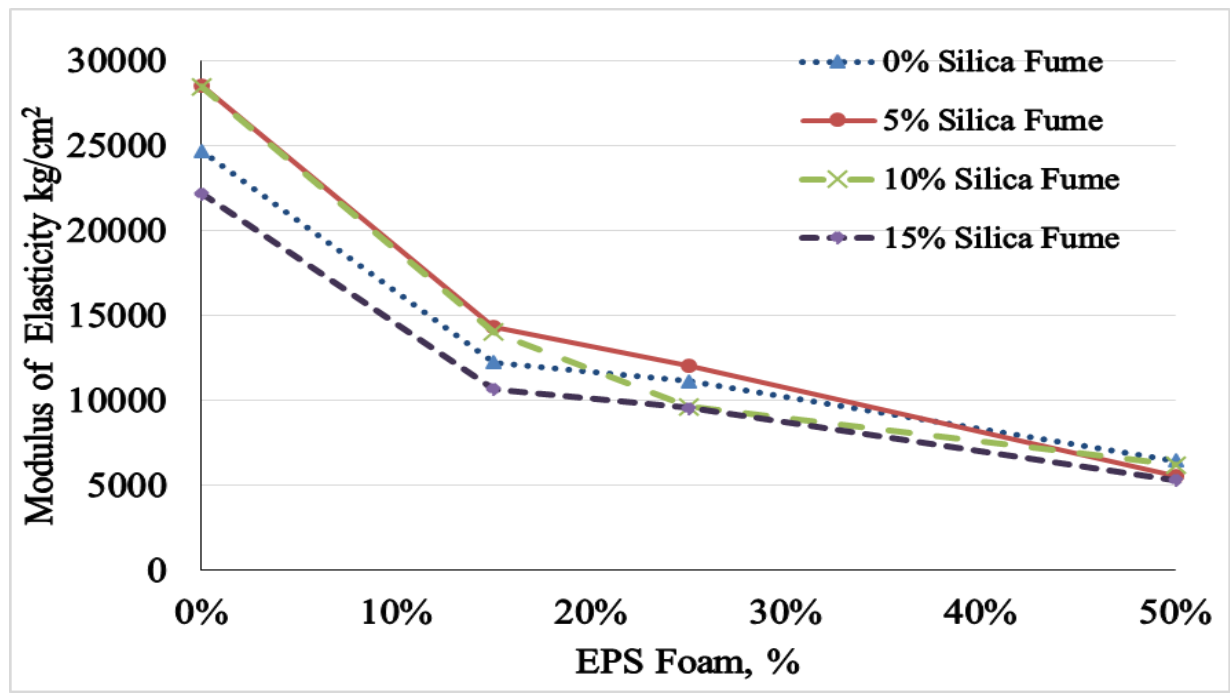

Figure 5: Effect of SF on modulus of elasticity of EPS foamed concrete

It is observed that, in contrast to NDC, the failure modes of all EPS foamed concrete percentages are gradual in different levels (Photo 2), and the specimens are capable of retaining the load after failure without full fragmentation. The gradual failure in EPS foamed concrete is mainly attributed to the good energy-absorbing quality of the EPS beads. It could be said that, the EPS foam concrete is high efficient at energy absorption capacity under compressive load. Similar results were obtained by $[\mathbf{5 , 3 0 ]}$.
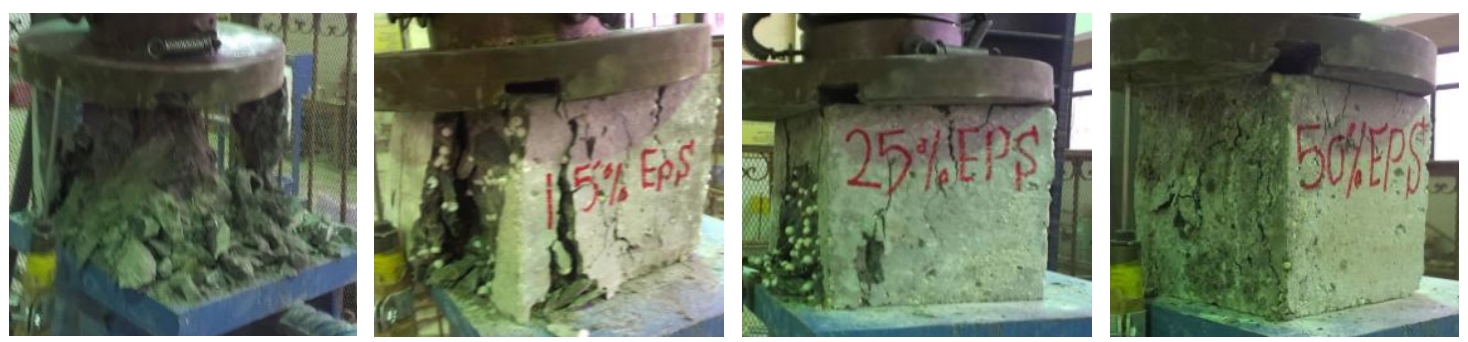

Fig. 2: Failure modes under compression of EPS foamed concrete defferent percentages specimens $(0 \%$, $15 \%, 25 \%, 35 \%$ and $50 \%$ ).

\section{CONCLUSIONS}

In this study, the effect of foam and SF content on the properties of EPS foamed concrete was investigated, and the results can be summarized as follows:

- Fresh EPS concrete density decreases with increasing ratio of EPS. The high amount of SF in EPS concrete reduces the fresh concrete density in all mixtures slightly.

- All EPS foam concretes without any special bonding agents show good consistency and could be easily compacted. The 5\% SF percentage improves the slump of EPS foamed concrete. The SF with ratios $10 \%$ and $15 \%$ enhances the EPS foamed concrete slump until the ratio of $25 \%$ EPS foam.

- There is no remarkable changes on hardened EPS concrete density at age of 7 days or 28 days while using SF in EPS foamed concrete, except the $15 \%$ SF content it reduces the hardened concrete density slightly.

- All mechanical properties studied have the same trend. It decreases with the increasing of EPS foam percentages in LWC.

- Compressive strength decrement of EPS foamed concrete at the age of 7 days is less than that at the age of 28 days.

- The difference of tensile strength decrement between early and late ages is significantly high in LWC with lower amount of EPS foam (15\% and 25\%), while the difference is low with high EPS foam percentages (50\%). 
- EPS foamed concrete with SF has ultimate percentage 5\% that gives maximum compressive strength and splitting tensile strength values. The $10 \%$ percentage of SF has a good effect on compressive strength in EPS foamed concrete till $25 \%$ EPS foam.

- The loss of flexural strength is noticeable at low levels of replaced EPS foam. At higher levels of replacing EPS foam the decrement in flexural strength is higher than tensile strength but lower than compressive strength. Flexural strength in EPS foamed concrete doesn't improve with the addition of SF.

- Modulus of elasticity for EPS foamed concrete is directly proportional with the density of concrete. SF with ratios 5\% and 10\% enhances the EPS foamed concrete modulus of elasticity until the ratios of $25 \%$ and $15 \%$ EPS foam respectively. The optimum percentage of SF that improves EPS concrete is $5 \%$.

\section{REFERENCES}

[1] Perez-Garcia, John, Bruce Lippke, David Briggs, James B. Wilson, James Bowyer, and Jaime Meil. "The environmental performance of renewable building materials in the context of residential construction." Wood and Fiber Science 37.12 (2005): 3-17.

[2] Bouvard, D., Jean-Marc Chaix, Rémi Dendievel, Arnaud Fazekas, J. M. Létang, G. Peix, and D. Quenard. "Characterization and simulation of microstructure and properties of EPS lightweight concrete." Cement and Concrete Research37.12 (2007): 1666-1673.

[3] Babu, Daneti Saradhi, K. Ganesh Babu, and Wee Tiong-Huan. "Effect of polystyrene aggregate size on strength and moisture migration characteristics of lightweight concrete." Cement and Concrete Composites28.6 (2006): 520-527.

51$\rceil$ Kan, Abdulkadir, and Ramazan Demirboğa. "A new technique of processing for wasteexpanded polystyrene foams as aggregates." Journal of materials processing technology 209.6 (2009): 2994-3000.

「5] Chen, Bing, and Ning Liu. "A novel lightweight concrete-fabrication and its thermal and mechanical properties." Construction and building materials 44 (2013): 691-698.

「6] Schackow, Adilson, Carmeane Effting, Marilena V. Folgueras, Saulo Güths, and Gabriela A. Mendes. "Mechanical and thermal properties of lightweight concretes with vermiculite and EPS using air-entraining agent." Construction and building materials 57 (2014): 190-197.

[71 Babu, D. Saradhi, K. Ganesh Babu, and T. H. Wee. "Properties of lightweight expanded polystyrene aggregate concretes containing fly ash."Cement and Concrete Research 35.6 (2005): 1218-1223.

「81 Kan, Abdulkadir, and Ramazan Demirboğa. "A novel material for lightweight concrete production." Cement and Concrete Composites 31.7 (2009): 489-495.

[9] Perry, S. H., P. H. Bischoff, and K. Yamura. "Mix details and material behaviour of polystyrene aggregate concrete." Magazine of Concrete Research 43.154 (1991): 71-76.

「101 Kan, Abdulkadir, and Ramazan Demirboga. "Effect of cement and EPS beads ratios on compressive strength and density of lightweight concrete."Indian journal of engineering \& materials sciences 14 (2007): 158-162.

「11] Xu, Yi, Linhua Jiang, Jinxia Xu, and Yang Li. "Mechanical properties of expanded polystyrene lightweight aggregate concrete and brick." Construction and Building Materials 27.1 (2012): 32-38.

[12] Madandoust, Rahmat, Malek Muhammad Ranibar, and S. Yasin Mousavi. "An investigation on the fresh properties of self-compacted lightweight concrete containing expanded polystyrene." Construction and Building Materials 25.9 (2011): 3721-3731.

「131 ACI Committee 116, Cement and concrete technology, ACI 116R- 00, ACI Committee 116 report, American concrete institute, Farmington, Hills, Michigan, 2000.

$\lceil 14\rceil$ Giorv, Vennesland $\varnothing$ and O.E, "Silica concrete protection against corrosion of embedded steel," Fly ash, silica fume, slag and other mineral by products in concrete, vol. 2, SP-79, American concrete institute, pp. 719-729, 1983.

「15] Thom Telford, "Condensed silica fume in concrete," State of the art report, FIP, London, p. 37, 1988.

[16] ACI Committee 234, Guide for the use of silica fume in concrete, ACI 234R-96, reapproved 2000, ACI Committee 234 Report," American Concrete Institute, Farmington Hills, Michigan, Reapproved 2000. 
「171 American Society for Testing and Materials. Standard specifications for Portland cement ASTM C150-85a; 1986. p. 114-20.

「181 Egyptian Code of Practice for Design and Execution of Concrete Structures, General Organization for Housing,Building and planning, Published in Giza, 2003.

「191 ASTM Committee C 511. Standard Specification for Mixing Rooms, Moist Cabinets, Moist Rooms, and Water Storage Tanks Used in the Testing of Hydraulic Cements and Concretes. Annual Book of ASTM Standards; 2004, 04.02.

「201 ASTM Committee C 138. Standard Test Method for Density (Unit Weight), Yield, and Air Content (Gravimetric) of Concrete. Annual Book of ASTM Standards; 2004, 04.02.

[211 ASTM Committee C 138. Standard Test Method for Slump of Hydraulic-Cement Concrete. Annual Book of ASTM Standards, 2004, 04.02.

[22] ASTM Committee C 567. Standard Test Method for, Density of Structural Lightweight Concrete. Annual Book of ASTM Standards, 2004, 04.02.

[23] ASTM Committee C 39. Standard test method for compressive strength of cylindrical concrete specimens. Annual Book of ASTM Standards, 2004, 04.02.

「241 ASTM Committee C 469. Standard Test Method for, Static Modulus of Elasticity and Poisson's Ratio of Concrete in Compression. Annual Book of ASTM Standards, 2004, 04.02. [25] ASTM Committee C 496. Standard Test Method for Splitting Tensile Strength of Cylindrical Concrete Specimens. Annual Book of ASTM Standards, 4, 2004, 04.02.

[261 ASTM Committee C 78. Standard Test Method for, Flexural Strength of Concrete (Using Simple Beam with Third-Point Loading). Annual Book of ASTM Standards, 2004, 04.02.

[27] Babu KG, Babu DS. Performance of fly ash concretes containing lightweight EPS aggregates. Cem Concr Compos 2004;26(6):605-11.

[281 Lo, Tommy Y., W. C. Tang, and H. Z. Cui. "The effects of aggregate properties on lightweight concrete." Building and Environment 42.8 (2007): 3025-3029.

「291 Holm, T. A. (1994). "Lightweight concrete and aggregates. In Significance of Tests and Properties of Concrete and Concrete-Making Materials." STP 169C, 522-32, P. Klieger and J. F. Lamond, eds., ASTM International, West Conshohocken, Pa.

「30] Cui, Chengchen, Qiang Huang, Dongbin Li, Chunri Quan, and Hongchao Li. "Stressstrain relationship in axial compression for EPS concrete." Construction and Building Materials 105 (2016): 377-383. 